\title{
INDUSTRIALIZATION AS A HISTORICAL
} PHENOMENON

\author{
Arnulf Grübler \\ International Institute for Applied Systems Analysis \\ Laxenburg, Austria
}

RR-95-9

November 1995

Reprinted from Chapter 4 of Industrial Ecology and Global Change, edited by R. Socolow, C. Andrews, F. Berkhout, and V. Thomas (Cambridge University Press).

INTERNATIONAL INSTITUTE FOR APPLIED SYSTEMS ANALYSIS Laxenburg, Austria 
Research Reports, which record research conducted at IIASA, are independently reviewed before publication. Views or opinions expressed herein do not necessarily represent those of the Institute, its National Member Organizations, or other organizations supporting the work.

Reprinted with permission from A. Grübler, "Industrialization as a historical phenomenon", in Industrial Ecology and Global Change, edited by R. Socolow, C. Andrews, F. Berkhout, and V. Thomas (Cambridge University Press).

Copyright (C)UCAR 1994

All rights reserved. No part of this publication may be reproduced or transmitted in any form or by any means, electronic or mechanical, including photocopy, recording, or any information storage or retrieval system, without permission in writing from the copyright holder.

Printed by Novographic, Vienna, Austria. 


\section{Foreword}

Concern about global environmental change has stimulated interest in the comprehensive analysis of waste streams and effluents from industrial activities. This comprehensive approach has been termed industrial "ecology" or industrial "metabolism". There are many valuable studies that give insights into the flows of hazardous substances like heavy metals or energy and greenhouse gas emissions from current industrial activities. A deeper understanding of industrial metabolism requires also information on how industrial structures have evolved historically and how they might change in the future.

The paper by Arnulf Grübler provides a much needed holistic account of the long-term history of industrialization. The paper also identifies patterns in the energy and carbon intensity of industrial activities that give reasons to be cautiously optimistic: the goal of higher productivity also translates into long-term tendencies of dematerialization and decarbonization of industrial activities. Historically, these improvements have, however, not been fast enough to offset the impact of vastly increased levels of industrial production.

Looking at production alone, however, may not be sufficient to steer the industrial metabolism onto more environmentally compatible development paths. Historically, productivity growth has led to higher incomes and a reduction in working time. The paper concludes that the biggest challenge ahead for industry is to extend the boundaries of industrial activities: providing consumers not only with products, but with environmentally friendly integrated solutions for satisfying particular service demands.

Nebojša Nakićenović

Project Leader

Environmentally Compatible Energy Strategies 


\title{
4 \\ Industrialization as a Historical Phenomenon
}

\author{
Arnulf Grübler
}

\begin{abstract}
Industrialization is described as a historical succession of periods of pervasive adoption of clusters of technological and organizational innovations. Combined they have enabled vastly rising industrial output, productivity, and incomes, as well as reductions in the amount of time worked. The resource and environmental intensiveness of different industrialization paths is illustrated with quantitative data on energy consumption and carbon emissions. It is concluded that industry in principle moves in the right direction of dematerialization and decarbonization; however, to date not fast enough to compensate for increasing output volumes. Continued structural change from industry to services and from work to pleasure will require a redefinition of the scope of industrial activities from artifacts to integrated solutions to satisfy consumer service demands in an environmentally compatible manner.
\end{abstract}

\section{Introduction}

Industrialization is a process of structural change. Sources of productivity and output growth as well as of employment move away from agriculture toward industrial activities, manufacturing in particular (Figures 1 and 2). Rising productivity and output in industry have been main drivers for economic growth and increased national and per capita incomes, which in turn provide an ever enlarging market for industrial products.

Like any pervasive process of economic or social change, industrialization is driven by the diffusion of many individual (but interrelated) innovations. These are not only technical, but also organizational and institutional, thus also transforming the social fabric. In fact, the term "industrial society" has come to describe a particular type of economic and social organization, from science and industrial management to the fine arts. An industrial society is based pervasively on the economics of standardization and specialization of human activities to produce, not only ever more, but, paradoxically, an ever larger variety of final products.

Industry is an important part of human activities and a powerful agent of global change. It accounts for about $20 \%$ of employment and $40 \%$ of value added, final energy consumption, and carbon emissions (Table 1). However, the relative 
Vulnerability and Adaptation

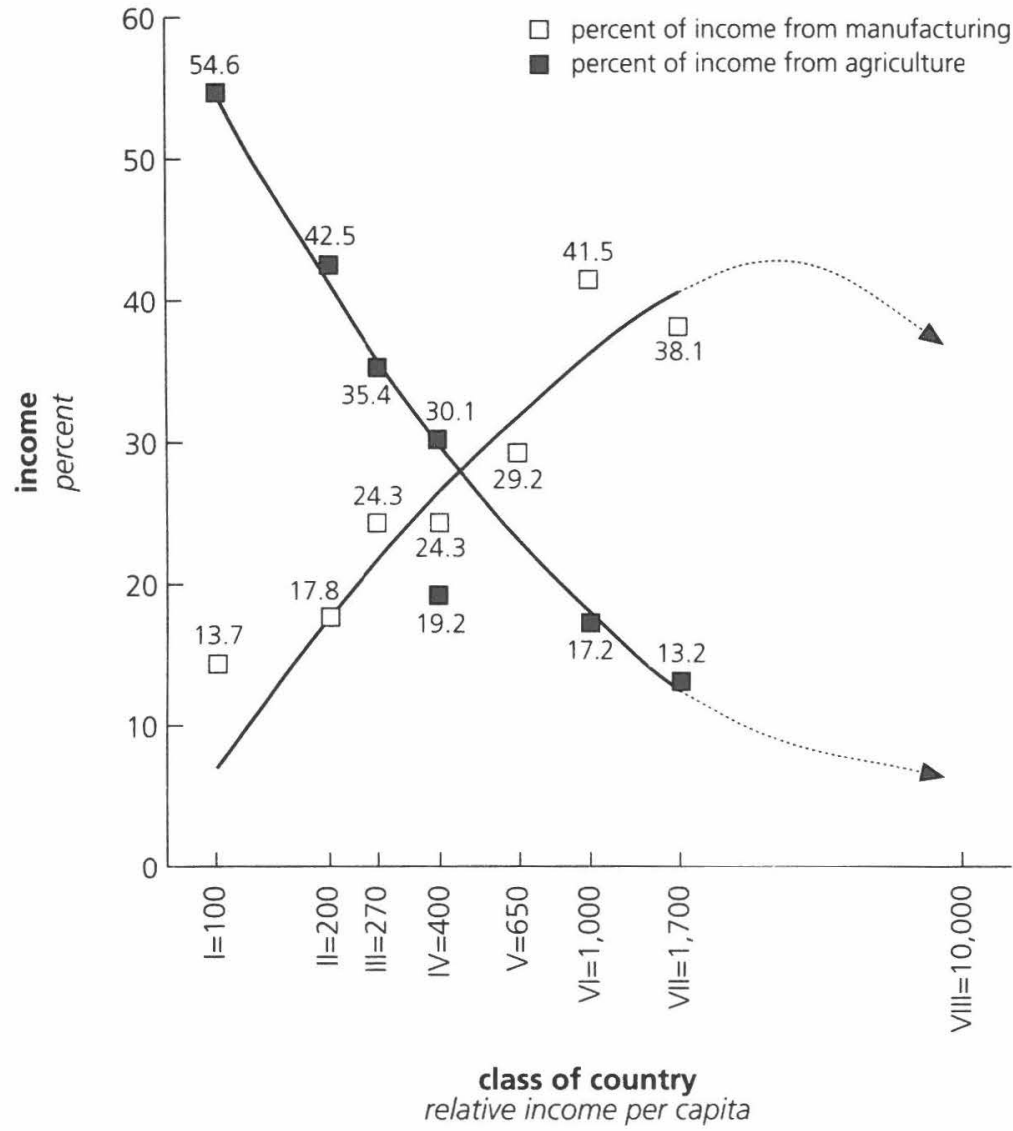

Figure 1. Industrialization as a process of structural change. Value generation and employment (cf. Figure 2 opposite) shift away from agriculture to industrial activities, manufacturing in particular. Source: Kuznets, 1958.

weight of industry varies widely in time and space primarily as a function of the degree of industrialization (or postindustrialization) and the overall level of economic development.

Since the middle of the 18th century, global industrial output and productivity have risen unimaginably. Based on updated estimates of Bairoch (1982), global industrial output has risen by about a factor of 100 since around 1750 . Over the last hundred years, industry has grown by a factor of 40 , or at an annual growth rate of about $3.5 \%$. Per capita industrial production increased over the same period by a factor of about 11 , or at a rate of $2.3 \%$ per year. This suggests that rising per capita activity levels were a more powerful agent of change than was human population growth. The growth in industrial labor productivity has been even more spectacular than output growth. Again the data are uncertain, but recent quantitative evidence does not change the impressive account of industrial productivity 


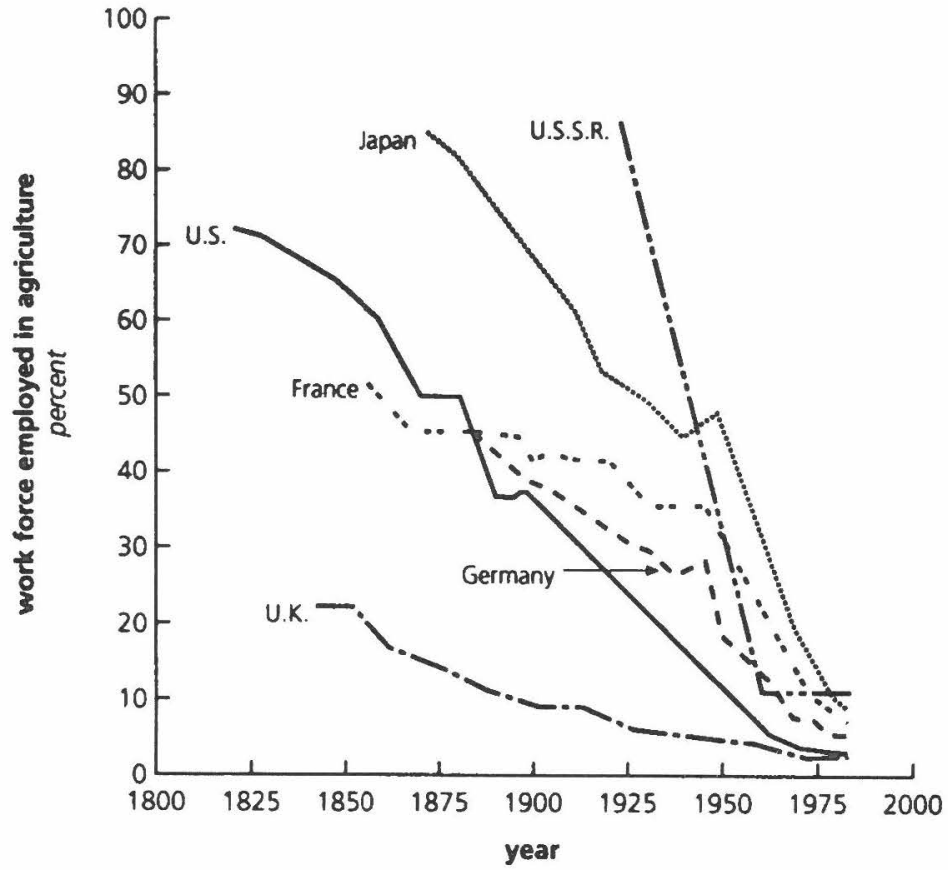

(a)

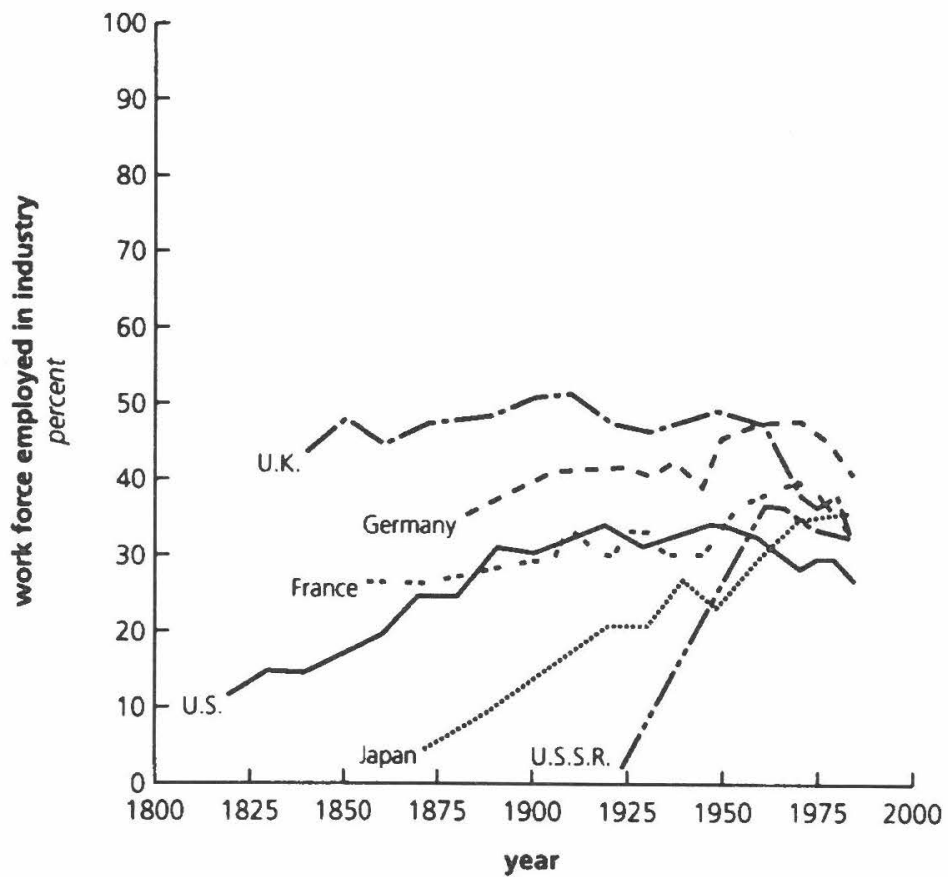

Figure 2. Industrialization as a process of change in occupational structure: (a) percentage of work force employed in agriculture vs. (b) percentage of workforce in industry. Note that industry now performs many activities previously residing in agriculture (from Nakićenović et al., 1990). 
Vulnerability and Adaptation

Table 1: Basic industrial activity data, 1990

\begin{tabular}{|c|c|c|c|c|c|c|}
\hline & & & $\begin{array}{r}\text { To } \\
\text { Seven Major }\end{array}$ & $\begin{array}{l}\text { of } \\
\text { ommodities }^{1}\end{array}$ & Final Energy & Tons of \\
\hline & $\begin{array}{l}\text { People } \\
\text { Employed } \\
\left(\times 10^{6}\right)\end{array}$ & $\begin{array}{l}\$ \text { Value } \\
\text { Added } \\
\left(\times 10^{9}\right)\end{array}$ & $\begin{array}{l}\text { Produced } \\
\left(\times 10^{6}\right)\end{array}$ & $\begin{array}{c}\text { Tons / km } \\
\text { Transported } \\
\left(\times 10^{12}\right)\end{array}$ & $\begin{array}{c}\text { Consumed } \\
\text { (w/o Feedstocks) } \\
(\mathrm{GW} / \mathrm{yr} / \mathrm{s})\end{array}$ & $\begin{array}{l}\text { Carbon } \\
\text { Emissions } \\
\left(\times 10^{6}\right)\end{array}$ \\
\hline $\begin{array}{l}\text { Market } \\
\text { economies }\end{array}$ & 130 & 4632 & 1095 & 6 & 1164 & 766 \\
\hline $\begin{array}{l}\text { Reforming } \\
\text { economies }\end{array}$ & 80 & 975 & 515 & 8 & 851 & 584 \\
\hline $\begin{array}{l}\text { Developing } \\
\text { economies }\end{array}$ & 300 & 1068 & 895 & 8 & 1116 & 733 \\
\hline World & 510 & 6675 & 2505 & 22 & 3131 & 2083 \\
\hline
\end{tabular}

${ }^{1}$ In decreasing order of global tonnage: cement, steel, paper, fertilizer, glass, aluminum, copper.

${ }^{2}$ Including manufacture of cement. Carbon emissions from electricity production allocated to industry in proportion of industrial to total electricity consumption.

Data sources: Economist, 1990; ILO, 1991; IRF, 1991; U.N., 1990.

growth in Colin Clark's (1940) classic Conditions of Economic Progress. Data indicate at least a factor of 200 improvement since the middle of the 18 th century. Thus, an industrial worker in the United States produces today in one hour what took a U.K. laborer two weeks of toiling 12-hour days some 200 years ago.

The growth in labor productivity illustrates the crucial role of technological and organizational change. Other factors important for industrialization include the availability of (skilled) labor, capital, energy and mineral resources, and to a lesser extent land and the productivity of the agricultural sector. The absolute and relative availability of factor inputs (e.g., the relative scarcity of labor vs. capital) influence historical industrialization paths and can also account for present differences in industry size, structure, and productivity among countries. In turn, technological change influences both the absolute and the relative availability of factor inputs to industry.

In highlighting technological, social, and organizational innovations as drivers of industrial growth, we seem to question the role of natural resource endowments. Is the availability of energy and mineral resources not a conditio sine qua non for industrialization? The author is inclined to consider resource availability as of secondary importance, especially for the industrial system, based on the spatial division of primary (raw materials) and secondary (manufacturing) activities that emerged with the availability of modern transportation systems since the 19th century. First, without technology no natural resource can be harvested and processed for input to industrial activities. Second, the availability of resources is itself a function of technology (via, e.g., geological knowledge, exploration and production technologies). Thirdly, technology development can provide for substitutes such as the replacement of natural nitrate by manmade fertilizers, or natural by synthetic rubber. 


\section{A. Grübler: Industrialization as a Historical Phenomenon}

From this perspective, different degrees of development and industrialization are technology gaps resulting from differences in accumulation and innovativeness, and not so much from resource endowments or scarcity. Innovative capacity (and thus production, income and growth possibilities) is created (among others by human capital and an appropriate socio-institutional framework), and not given. Historical analysis indicates a number of cases where successful industrialization was achieved even with only modest national natural resource endowments (e.g., France, Scandinavia, Austria, Japan). Considering the resource and environmental intensiveness of different industrialization paths (discussed below), the abundance of resources even could be a mixed blessing. One might wonder if coal-rich China will develop along the energy-intensive development path of the United States, or alternatively along more energy-efficient pathways of industrialization as in the French or Japanese experience.

\section{The Spread of Industrialization: Technology Clusters, Sources of Growth, and Spatial Heterogeneity}

Below we illustrate that industrialization, embedded within a broader framework of economic growth, proceeded through a succession of development periods based on the pervasive adoption of various "technology clusters," i.e., a set of (interrelated) technological, organizational and institutional innovations driving industrial output and productivity growth. Such a succession is, however, not a rigid temporal sequence as various clusters coexist (with changing weights) at any given time. Older technological and infrastructural combinations coexist with the dominant technology cluster, and in some cases previous clusters (compared to the dominant technology base in the leading industrialized countries) are perpetuated, as was largely the case in the post-World War II industrial policy of the former USSR.

At any time most industrial and economic growth is, however, driven by the dominant technology cluster, frequently associated with the most visible technological artifact or infrastructural system (or "leading sector") of the time (e.g., the "railways era" [Schumpeter, 1939] or the "age of steel and electricity" [Freeman, 1989]). We emphasize the concept of technology clusters because studies under the leading sector hypothesis (e.g., Fishlow, 1965; O'Brien, 1983; Tunzelmann, 1982) have shown that these can explain only a fraction of economic and industrial growth. Only the combination of a whole host of innovations in many sectors and technological fields can account for sustained industrial and economic growth.

Table 2 is an attempt to categorize various phases of industrial and economic development through the concept of technology clusters. It lists the dominant cluster in the top row and the emerging cluster (dominating in the successive phase) below. Examples of key technologies in the areas of energy and transport systems, materials and industry, and the final consumer sphere are listed. Finally, we categorize the dominant "organizational style" (Perez, 1983), i.e., the predominant mode regulating industrial, economic, and social relations, and give a geographical 
Table 2: Important technology clusters for economic growth and industrialization

\begin{tabular}{ccccc}
\hline \hline & $1750-1820:$ & $1800-1870:$ & $1850-1940:$ & $1920-2000:$ Mass \\
Cluster & Textile & Steam & Heavy Engineering & Production/Consumption \\
\hline
\end{tabular}

\section{Dominant}

Energy

Transport and

Water, wind, feed, wood Wood, feed, coal

communication

Materials

Industry

$\stackrel{\infty}{\infty}$

Consumer products Textiles (wool, cotton), Textiles, chinaware pottery

$\begin{array}{lll}\begin{array}{l}\text { Emerging } \\ \text { Energy } \\ \text { Transport and } \\ \text { communication }\end{array} & \begin{array}{l}\text { Coal, coke } \\ \text { Canals }\end{array} & \begin{array}{l}\text { City gas } \\ \text { Mobile steam, } \\ \text { telegraph }\end{array} \\ \text { Materials } & \text { Puddling steel } & \text { Mass produced steel } \\ \text { Industry } & \begin{array}{l}\text { Stationary steam, } \\ \text { mechanical equipment } \\ \text { Consumer products }\end{array} & \begin{array}{l}\text { Coal chemicals, dyes, } \\ \text { Structural materials } \\ \text { Illuminants }\end{array}\end{array}$

Consumer products mechanical equipmen

Illuminants

\section{Coal}

Railways, steamships,

telegraph

Stcel

Stationary steam, mechanization

Product diversification (imports)

Heavy machinery, chemicals, structural materials

Oil, electricity

Roads and cars,

telephone, radio

Synthetics, aluminum

Fine chemicals, drugs, durables

Consumer durables,

refrigeration

\section{Oil, electricity \\ Roads, telephone radio, and TV}

Petrochemicals, plastics, Alloys, specialty materials steel, aluminum

Process plants,

numerically-controlled machinery, consumer

goods, drugs

Durables, food industry, Leisure and vacation,

tourism

custom-made products

Gas, nuclear

Air transport,

telecommunication, computers

"Custom-made" materials, composites

Electronics, information technologies

Gas, electricity

Roads, air transport,

multimedia

Environmental

technologies, disassembly and recycling, consumer services

Hydrogen?

Hypersonic? high-speed

trains

Recyclables and degradables

Services (software) biotechnologies

Leisure and recreation Integrated "packages"

products, arts (products + services) 
Organizational Style

Plant/company leve

Individual Small firms, joint

entrepreneurs, local

capital, small-scale

manufacture

Economy and society Breakdown of feudal

and medieval economic Manchester liberalism

structures

Industrial Geography

Core

England

England, Belgium

Germany, USA

Benelux, France,

England

Rim

Belgium, France

Central Europe, Italy,

Scandinavia, Canada

JANZ', Russia
Fordism/Taylorism,

multinationals, vertica

integration

Social welfare state

Keynsianism, "open"

society

USA, Canada, JANZ,

European Community

England

USSR, Central and

Eastern Europe,

Southern Europe
"Just-in-time," Total quality control (TQC),

horizontal integration

Economic deregulation, environmental regulation, networks of actors

OECD

4 Tigers, ${ }^{2}$ Russia, Centra and Eastern Europe, ??

JANZ = Japan, Australia, New Zealand

24 Tigers describes the dynamic rapidly industrializing economies of Asia: Hong Kong, Singapore, South Korea, and Taiwan. 


\section{Vulnerability and Adaptation}

taxonomy ${ }^{1}$ of centers of industrialization ("core") and regions catching up (newly industrializing or "rim" countries). All regions/countries not listed separately in Table 2 are classified as "industrial periphery" for the purposes of this discussion.

Four historical and a prospective fifth future cluster are identified, named after their most important carrier branches or functioning principles. These are: the textile industrialization cluster, extending to the $1820 \mathrm{~s}$; the steam cluster until about the 1870s; heavy engineering, lasting until the eve of World War II; and mass production/consumption until the 1970s and 1980s. Currently we appear in the transition to a new age of industrialization. Both its characterization as a "total quality" cluster (i.e., with control of both the internal and external, or environmental, quality of industrial production) and the technological examples given are necessarily speculative.

It has to be emphasized that the classification presented in Table 2 is a crude one and the examples are illustrative, not exhaustive. Also the timing of the various clusters in Table 2 is only approximate. In view of space limitations, the following qualitative $^{2}$ discussion of Table 2 will be brief and (over)simplified.

\section{0-1820: Textiles}

Industrialization as a process of structural change began in 18th-century England. Technological innovations transformed the manufacture of textiles and gave rise to what later became a new mode of production: the factory system. Important bottlenecks for industrialization and its concomitant spatial concentration of population and economic activities began to be overcome. Coal and Darby's coke combined with the stationary steam engine (particularly important for coal mine dewatering) put an end to fuelwood and charcoal shortages and provided for spatial power densities previously found only in exceptional locations of abundant hydropower. The improvements in parish roads and turnpikes and especially the "canal mania" around the turn of the 19th century enabled the supply of rapidly rising urban and industrial centers with food, energy, and raw materials. Charcoal and the puddling furnace produced the first industrial commodity and structural material: wrought iron. Innovations in spinning (and after the 1820s also in weaving) enabled falling costs and rising output, particularly in the manufacture of cotton textiles. The introduction of fine porcelain from China gave rise to an expanding chinaware industry.

\footnotetext{
1 This taxonomy is introduced to account for persistent spatial disparities in levels of industrialization, technology base, and degree of interconnectedness (exchange of information and goods) between countries/regions. Note that this is a functional categorization and not necessarily one based on geographical proximity. For similar concepts discussed within the framework of sustainability, see Brooks, 1988.

${ }^{2}$ For a quantification using principal component analysis see Glaziev, 1991; for an analysis based on innovation diffusion cf. Grübler (1990). The rise (and fall) of particular "technology clusters" has also been described using particular sectors or representative technologies (e.g., energy and transport infrastructures) as "metaphors." In view of abundant literature (e.g., Hoffmann, 1931, 1958; Woytinsky and Woytinsky, 1953; Landes, 1969; Rostow, 1978; Mokyr, 1990) containing valuable historical data and easily available output statistics of principal industrial commodities (e.g., Mitchell, 1980, 1982, 1983), this information is not further discussed here.
} 


\section{A. Grübler: Industrialization as a Historical Phenomenon}

The nexus of innovations involving cotton textiles, the coal and iron industries, and the introduction of steam power constitute the heart of England's Industrial Revolution. However, in order for these developments to take place, important preconditions must be mentioned. More complex crop rotation patterns, abandonment of fallow lands, field enclosures, new crops, and improved animal husbandry allowed fewer people to grow more food (cf. Grigg, 1987; Grübler, 1992). Freed from agriculture, people sought urban residence and industrial employment. In the institutional sphere, the separation of political and economic power, new institutions for scientific research and dissemination of its results, organization of market relations, etc., all mark the breakdown of feudal and medieval economic structures with their associated monopolies, guilds, tolls, and restrictions on trade. Perhaps the intellectual and institutional/organizational changes were indeed the most fundamental (Rosenberg and Birdzell, 1986) as enabling and encouraging changes in the fields of industrial technology, products, markets, infrastructures, etc. Under a general laissez faire attitude, no provision was made to socially smooth the disruptive process of structural change in employment, rural-urban residence, value generation, and distribution of income, leading to violent manifestations of social and class conflict (e.g., Luddists, or the Captain Swing movement; cf. Hobsbawn and Rudé, 1968).

\section{0-1870: Steam}

In this period, lasting to the recession in the 1870 s, industrialization emerges from a spatially and sectorally confined phenomenon to a pervasive principle of economic organization. Industrialization continues to be dominated by England, which reaches its apogee as the world's leading industrial power by the $1870 \mathrm{~s}$, accounting for nearly one-quarter of the global industrial output. Industrialization spreads to the continent (Belgium, and the Lorraine and the Ruhr in France and Germany, respectively) and to the eastern United States much along the lines of the successful English model (textiles, coal and iron industry).

Coal (fuelwood in the United States) provides the principal energy form for industry, whereas transportation and household energy needs continue to be supplied mostly by renewable energy sources (animal feed and wood). The steam period is characterized by the emergence of mobile steam power (locomotives and boats), but transport infrastructures are still dominated by inland navigation and canals, reaching their maximum network size by the 1870s (in England, France and the United States). Important innovations emerge in the fields of materials (Bessemer steel production), transport and communications (railways and telegraphs), energy (city gas), and the (coal-based) chemical industry. These were to become the dominant technological cluster of the second half of the 19th century until the Great Depression of the 1930s.

\section{0-1930: Heavy Engineering}

Fueled by coal, this industrialization phase is dominated by railways, steam, and 


\section{Vulnerability and Adaptation}

steel: it is the most smokestack-intensive period of industrialization. Dominated by the output of primary commodities and capital equipment, the industrial infrastructure spreads on a global scale. Enlarging the industrial and infrastructural base becomes almost a self-fulfilling purpose, driven by economies of scale at all levels of industrial production and organization. Standardization of mass-produced components and structural materials, perhaps best symbolized by the Eiffel Tower, is another characteristic of heavy engineering.

England loses its position as industrial leader (in terms of production and innovations) to Germany and the United States. The latter emerges as the world's largest industrial power by the 1920 s, accounting for $40 \%$ of global manufacturing output (Bairoch, 1982), 60\% of world steel production (Grübler, 1987), and $80 \%$ of cars registered worldwide (MVMA, 1991).

Railway networks and ocean steamships draw distant continents into the vortex of international trade, dominated by the industrialized core countries. Free world trade, greatly facilitated by the universal adoption of the Gold Standard, grows exponentially, but its political counterparts are imperialism and colonialism. Trade flows are dominated by trade between the industrialized core countries (see Table 2) and the rapidly industrializing rim (Russia and Japan). The industrial periphery (regions with the weakest industrial base) provides ever-enlarging markets for the products of the industrialized core and supplies raw materials and food (long-distance trade being made possible after the invention of canned food and refrigeration).

The pace of technological change accelerates with the emergence of oil, petrochemicals, synthetics, radio, telephone, and, above all, electricity, but the institutional and regulative picture is less progressive. Emerging industrial giants, monopolies, and oligopolies, perhaps best symbolized by Rockefeller's Standard Oil Company, are at the focus of government regulatory efforts, while social issues are only beginning to be tackled. Legislation to limit child labor, provide for elementary health care, and reduce long working days (up to 16 hours per day) is introduced at a slow pace and implemented at an even slower one. Dissatisfaction with the prevailing capitalistic accumulation regime stimulates the development of alternative theoretical expositions (Marxism) and the emergence of new social movements (the labor movement, trade unionization), aiming at a more equitable distribution of productivity gains. Workers reap some of the benefits in the form of increasing employment, falling real-term prices of food and manufactured products, and (to a smaller extent) rising wages. But the inability of the social/institutional framework to provide for a more equitable distribution of productivity gains causes increased social conflicts. These begin to be resolved only by progressively internalizing labor costs into the economics of industrial growth, as symbolized by the social welfare state emerging in the 1920s.

\section{0-1980: Mass Production/Consumption}

The post-World War II economic boom was based on a cluster of interrelated technical and managerial innovations, leading to productivity levels clearly superior to 


\section{A. Grübler: Industrialization as a Historical Phenomenon}

those of the heavy engineering paradigm. The extension of the continuous flow concept of the chemical industry to the mass production of identical units enabled unprecedented real-term cost and price decreases and thus mass consumption. Typical products include the internal combustion engine and the automobile, petrochemicals and plastics, farm machinery and fertilizers, consumer durables, etc. The prototype of the associated production organization was the Fordist assembly line, complemented on the organizational level by a separation of management and administration from production along the ideas of Taylor's scientific management. Additional economies of scale were realized by the increasing vertical integration of industrial activities and the emergence of enterprises operating on a global scale (multinationals).

New energy, transport, and communication infrastructures proved vital. Petroleum was available at low (real-term) costs and became the principle energy carrier and feedstock. Roads and vehicles powered by internal combustion engines (cars in market economies and buses in formerly planned and in developing economies) replaced railways as dominant transport systems. Air transportation and global communication networks (telephone, radio, and TV) have not only reduced physical distances but also enhanced cultural and informational interchanges. Science has grown "big" (de Solla-Price, 1963) and has been integrated systematically into industrial activities, from industrial R\&D laboratories to product quality control and even consumer research.

Although industrialization has become a global phenomenon, an analysis reveals only a few examples of successful catching up (notably Japan). Instead, catching up happens more within given geographical regions or between regions with not too different degrees of industrial development. In terms of the spatial taxonomy adopted here, this implies that some former members of the industrial rim (Canada, Japan, Scandinavia, Austria, Switzerland, Italy) have joined the core, but the dominance of the core is as great as ever. The members of the Organization for Economic Cooperation and Development (OECD) countries account for $70 \%$ of the world's industrial output and for $75 \%$ of the world merchandise trade (World Bank, 1992). Over $80 \%$ of OECD's imports of manufactured goods is imported from other OECD members, another $9 \%$ from the industrial rim (Eastern Europe and 4-Tigers), and only about $10 \%$ from the rest of the world (World Bank, 1992).

Examples of the social-institutional framework associated with the mass production/consumption regime include Keynsian policies leading to various forms of demand management (enabling mass consumption) via public infrastructure, defense, and public service spending, and via income redistribution (the welfare state). Other examples include socio-institutional innovations such as large-scale consumer credits, publicity, development of mass communication, institutional embedding of labor unions, or the development of various forms of Sozialpartnerschaft as the institutional framework of a social consensus on the general growth trajectory. However, it appears that we are witnessing a widening mismatch (Perez, 1983) between this socio-institutional framework and the 


\section{Vulnerability and Adaptation}

attainment of (market, environmental, and social acceptance) limits to the further expansion of its production/consumption paradigm.

\section{Industrialization: Output and Productivity Growth}

Estimates of global industrial output growth (Rostow, 1978; Bairoch, 1982; Haustein and Neuwirth's 1982 update of Hoffmann, 1958) indicate a growth over the last 100 years of some $3.5 \%$ annually. Although estimates differ on global industrial growth during the early industrialization phase, they agree on an exponential growth pattern since the latter half of the 19th century. This, however, applies only to estimates of the monetary value of industrial output and not to its physical equivalent. The material intensiveness of industrial output varies over time and, especially in the OECD countries, has been declining for decades (cf. Williams et al., 1987).

Table 3 summarizes the geographical distribution of industrial output growth, following the spatial taxonomy adopted here. Based on Bairoch's estimate, the industrial output of England in 1900 is used as normalizing index. Thus, Table 3 indicates that the industrial output of England in 1900 approximated that of the entire globe 150 years earlier. Conversely, global industrial output in 1980 was a factor over 100 larger than in England 80 years earlier. Since the mid-19th century, the industrialized core countries account persistently for up to two-thirds of global industrial output. Table 3 indicates that the industrial core has persistently higher growth rates than the rim and periphery. Only in 1930-80 does the rim show higher growth rates than the core, i.e., it is catching up. But the absolute and relative gap between the industrial core and the periphery widens. It is beyond the scope of this chapter to discuss reasons (or possible remedies) for persistent, even widening, disparities in levels of industrial development. One frequent argument points to falling real-term primary resource prices and resulting deteriorating terms of trade. However, one has also to keep in mind the constant change in the industrial structure of the core, and especially its falling materials intensity. Thus, deteriorating terms of trade can partly explain why industrial growth rates in the periphery were smaller than to be expected from their factor endowments. However, they are an insufficient explanation for the persistently higher growth rates in the core. Instead, the success of the core appears more related to its dynamics of industrial innovation and the resulting rise in factor productivity.

Figure 3 presents estimates of the improvement in labor productivity in manufacturing for a number of industrialized countries. The international comparison of industrial and manufacturing labor productivity is far from easy. Differences in industrial output mix, relative price structure, exchange rates, labor qualification, industrial relations, hours worked, etc., still await definitive methodological and empirical resolutions. Therefore, the data primarily illustrate the evolution of labor productivity over time within a given country, rather than serving as a yardstick for international comparisons. 
Table 3: The global geography of industrialization (level of industrialization in the U.K. in $1900=100$ )

\begin{tabular}{|c|c|c|c|c|c|c|c|c|c|c|}
\hline & & & & & & & & & & 1980 \\
\hline & 1750 & & $1830 \mathrm{~s}$ & & 1870 s & & $1920 \mathrm{~s}$ & & 1980 & 1750 \\
\hline \multicolumn{11}{|l|}{ Level in: } \\
\hline Core & 2 & & 20 & & 180 & & 950 & & 7400 & 3080 \\
\hline $\operatorname{Rim}$ & 5 & & 20 & & 40 & & 190 & & 2300 & 430 \\
\hline Periphery & 120 & & 145 & & 100 & & 220 & & 1300 & 11 \\
\hline World & 127 & & 185 & & 320 & & 1360 & & 11000 & 87 \\
\hline \multicolumn{11}{|c|}{ Growth rates, \%/yr: } \\
\hline Core & & 2.6 & & 4.6 & & 3.6 & & 4.0 & & 3.6 \\
\hline Rim & & 1.7 & & 1.3 & & 3.3 & & 5.0 & & 2.7 \\
\hline Periphery & & 0.2 & & -0.7 & & 1.7 & & 3.5 & & 1.1 \\
\hline World & & 0.5 & & 1.1 & & 3.1 & & 4.1 & & 2.0 \\
\hline \multicolumn{11}{|c|}{ Regional shares, \%: } \\
\hline Core & 2 & & 10 & & 56 & & 70 & & 67 & \\
\hline $\operatorname{Rim}$ & 4 & & 11 & & 12 & & 14 & & 21 & \\
\hline Periphery & 94 & & 79 & & 31 & & 16 & & 12 & \\
\hline
\end{tabular}

All figures rounded. Regional shares and factor increases calculated from original data may differ from rounded figures.

Data source: Bairoch, 1982.

Persistent differences in levels of labor productivity in manufacturing among the industrialized countries (not to mention the developing ones) emerge from Figure 3. Apparently, distinct national industrial systems (in terms of sectoral structure, technology base, etc.) with associated institutional settings (working time regulation, wage negotiation, etc.) have evolved. The cumulativeness of such industrialization paths is responsible for persistent differences in productivity despite intense international trade and competition. Some of the historical differences can also be related to the relative availability of various factor inputs. For example, labor was comparatively scarce for U.S. industry. Consequently, compared to that of England, U.S. industrial labor productivity was already higher when the U.S. was still a newly industrializing country.

\section{Industrialization and Environment}

The environmental implications of industrialization can perhaps best be described by Gray's (1989) paradox of technological development. Industrialization has brought unprecedented levels of environmental impacts stemming from effluents whose impacts are fairly well understood. It has also introduced new materials and substances (e.g., chlorofluorocarbons) with hitherto unknown impacts on the envi- 


\section{Vulnerability and Adaptation}

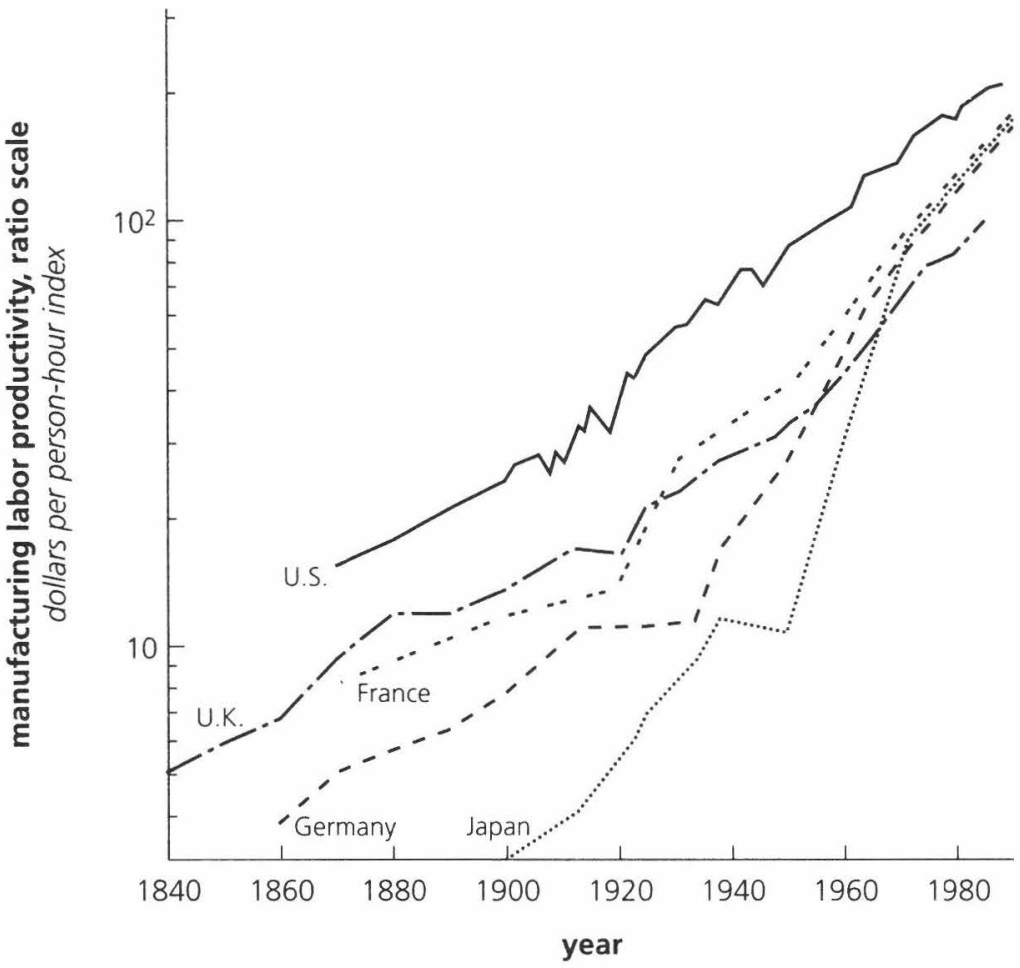

Figure 3. Growth in manufacturing labor productivity (in $\$$ per person-hour) index, ratio scale. Comparative productivity levels are only approximate; therefore weight should be given only to the relative evolution of productivity in a given country over time. Industrial labor productivity gains have been extraordinary and have allowed rising incomes (wages) and shortening of working hours. Industrial output and employment data are from Liesner, 1985, and Mitchell, 1980, 1983; working hours from Maddison, 1991. Productivity figures between 1840 and 1930 have been harmonized with the estimates of Clark, 1940.

ronment. But at the same time, the technological change that goes along with industrialization and the growing incomes generated by rising productivity have also enhanced our technological and economic capacities for remedies.

Industry has built in an inherent incentive structure to minimize factor inputs. This is primarily driven by economics and by continuous technological change. Therefore, industry moves in the right direction, and the real issue is how to accelerate this desirable trend. "The right direction" means, in principle, two things: (1) minimizing resource inputs per unit of economic activity, i.e., dematerialization, and (2) improving the environmental compatibility of the materials ssed, processed, and delivered by industry, i.e., with respect to industrial snergy use, decarbonization. Energy-related carbon emissions are the largest slobal expression of industry's metabolism, hence they are used as an illustration selow. 


\section{A. Grübler: Industrialization as a Historical Phenomenon}

\section{Toward Industrial Dematerialization and Decarbonization}

An analysis of industrial energy intensity per unit value added over time shows two important trends: decreasing energy intensities in the industrialized countries, and increasing intensities in newly industrializing ones. The much higher energy input per unit value added in the latter is frequently interpreted as potential for short- to medium-term energy efficiency improvements. However, higher energy intensities are in most cases the result of differences in degrees of industrialization and resulting differences in the structure and technology base of industry. This is illustrated in Figure 4, where the industrial energy intensity per unit value added is plotted against per capita levels of industrial value added. From such a perspective, the energy intensity of the Brazilian industry is in fact quite similar to that of the Japanese at similar levels of industrial per capita output. Conversely, the Nigerian example gives rise to concerns: increasing intensities of factor input use, but no significant growth in per capita levels of industrial output. The most spectacular improvements in industrial energy intensity were achieved in South Korea, illustrating that rapid industrial development and vigorous efficiency improvements are not mutually exclusive. Again, we observe only conditional convergence between countries and persistent differences between intensity "trajectories" of industrial development (e.g., United States vs. Japan).

The existence of specific industrialization trajectories illustrated above is also consistent with comparative macroeconomic studies of industrial development. Chenery et al. (1986) developed a typology of industrialization paths based on a differentiation of three classes of variables: size of the economy (small vs. large), sector orientation (primary vs. manufacturing), and trade orientation (inward vs. outward orientation). Over the post-World War II period, the highest industrial growth rates in semi-industrialized countries were achieved in small, manufacturing, and outward-oriented economies. Convergence is confined to countries belonging to a particular typological group rather than existing between groups. Chenery's typology constitutes an important differentiation of Rostow's (1978) stage theory of economic development. Instead of a single linear development model, a number of distinct development trajectories exist. Success appears also to be contingent on developing at least part of the industrial base on the technological productivity frontier. Perhaps the former USSR, or China's experience with rapid industrialization during the Great Leap Forward, can provide lessons on the feasibility of industrialization based on outdated technological vintages and industrial structures.

Figure 5 illustrates industrial carbon emissions as an environmental indicator of industrialization. An analog to Figure 4, it shows the industrial carbon intensity vs. per capita levels of industrialization. Carbon emissions from electricity generation are attributed to industry in proportion to industry's share in total electricity consumption and based on the (changing) average fuel mix in electricity generation. Overall, the decreasing carbon intensity of industrial activities is dominated by improvements in energy efficiency (cf. Figure 4). 
Vulnerability and Adaptation

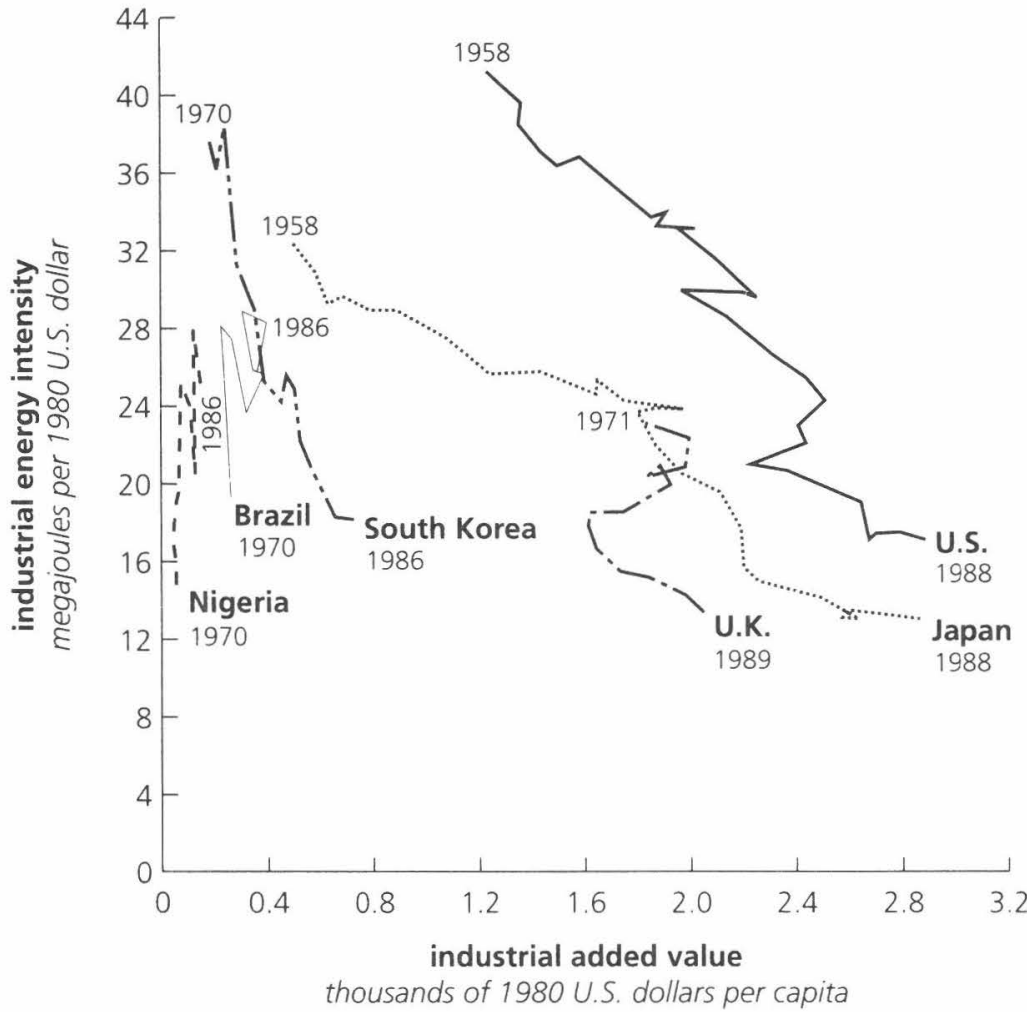

Figure 4. Industrial energy intensity vs. degree of industrialization as a more functional scale to assess the evolution of industrial energy intensity. Data from: Lawrence Berkeley Laboratory (LBL) data base and IEA, 1991.

Another factor explaining differences in industrial carbon intensity and its changes over time are changes in the structure of the industrial output. For instance, about $50 \%$ (some 230 million tons C) of U.S. industrial carbon emissions result from products contributing only to $15 \%$ (some $\$ 200$ billion) of the industrial value added, whereas $50 \%$ ( $\$ 780$ billion) of the industrial value added is produced with only $13 \%$ (60 million tons $\mathrm{C}$ ) of the sector's carbon emissions (Marland and Pippin, 1990). The skewed distribution function of industrial carbon emissions (Figure 6) indicates the importance of changes in the output mix, albeit these are difficult to model, yet to predict.

\section{A Case Study of Carbon Emissions in the U.S. Steel Industry}

This section uses the U.S. steel industry to illustrate the importance of structural shifts in process technologies and energy supply mix in moving in the direction of industrial dematerialization and decarbonization. Figure 7 illustrates specific and total sector carbon emissions since the middle of the second half of the 19th 


\section{A. Grübler: Industrialization as a Historical Phenomenon}

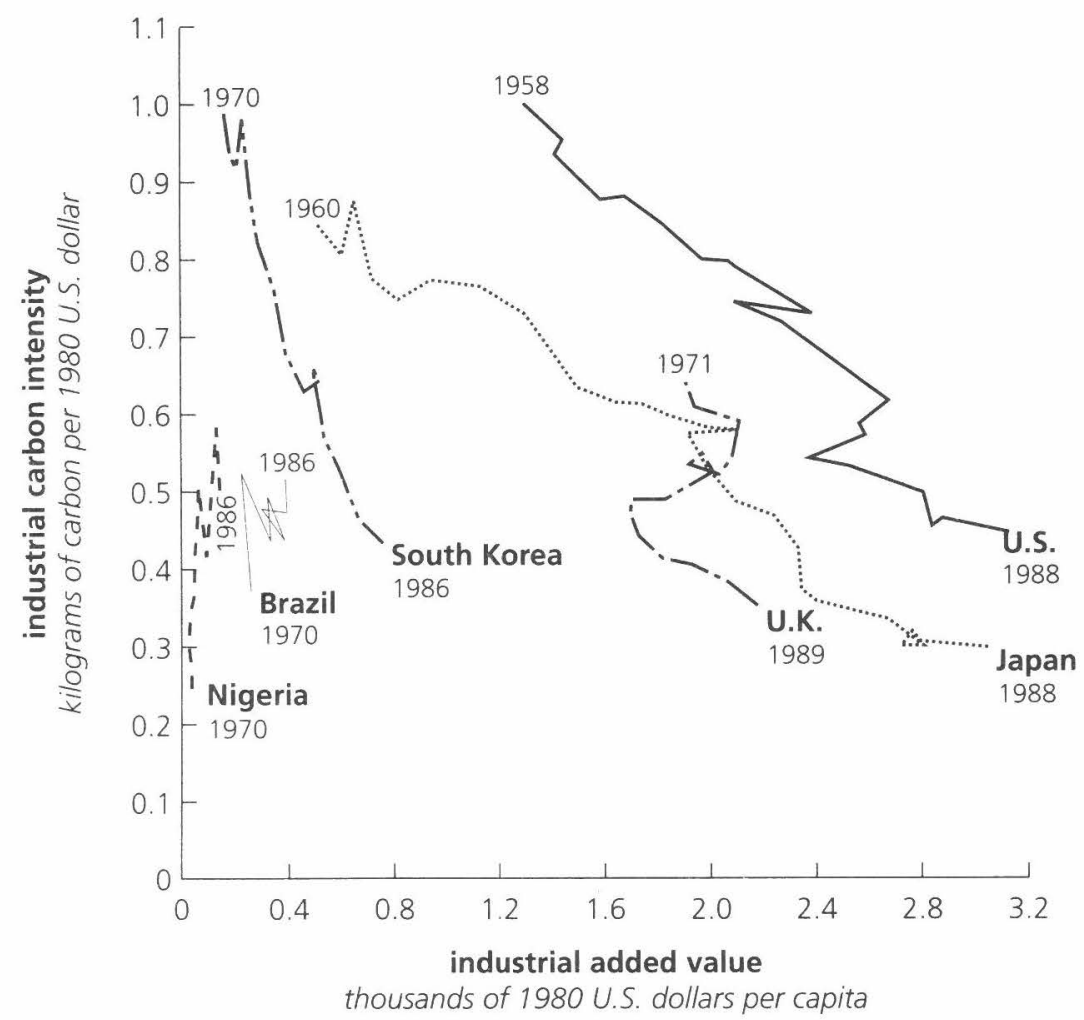

Figure 5. Industrial carbon intensity (kg C per U.S. \$ 1980 value added) versus per capita level of industrialization (1000 U.S. \$ 1980 per capita), cf. Figure 4 above. Data source: energy and value added: LBL data base, carbon emissions: emission factors based on Ausubel et al., 1988; electricity production structure from IEA, 1991.

century. Although minimizing carbon emissions has not yet been on the agenda of the industry, it is interesting to note the significant improvement (factor of 20) in the carbon emissions per ton (pig iron) produced. The secular trend follows a typical industrial learning curve when plotted against the cumulative output as done in Figure 7. Thus, specific carbon emissions decrease by $17 \%$ for each doubling of cumulative output. As significant as these improvements have been, their rate has fallen short of output growth. Consequently, total sector emissions (including emissions from the generation of the electricity consumed by industry) have increased over time, but apparently have already passed through their historical maximum. However, the important point here is to compare actual emissions with what they would have been if growth had been achieved by simply intensifying existing production methods. (In reality, the tremendous output increases could only be sustained precisely because of technological change.) The historical role of technology change has been, therefore, twofold: first, enabling significant output growth (and emissions) and, second, at 


\section{Vulnerability and Adaptation}

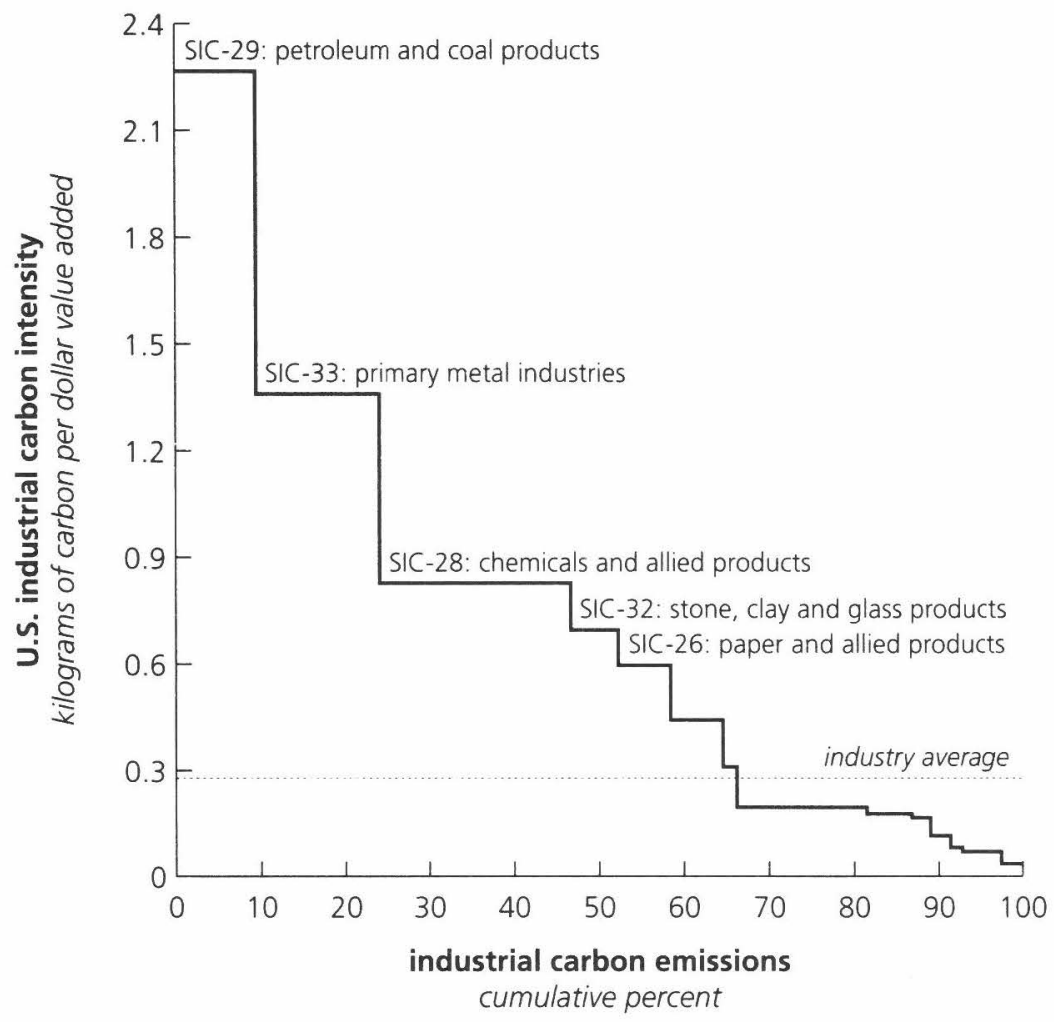

Figure 6. 1987 distribution of U.S. industrial carbon emissions by carbon intensiveness $(\mathrm{kg}$ C per $\$$ value added) for 2-digit SIC-code level product categories. The heterogeneity of the emission intensiveness between different industrial products indicates the importance of changes in industrial output mix for lowering overall specific industry emissions. Data source: Marland and Pippin, 1990.

the same time averting even worse impacts, due to significant efficiency improvements.

Improvements in the carbon intensity of steel manufacture were achieved by a combination of gradual, incremental, and radical changes in both process technology (Figure 8) and the energy supply mix (Figure 9). These two sets of changes operating in tandem are yet another illustration of the importance of interlinkages among different technological systems. Changes in the fuel mix are closely tied to changes in industrial process technologies and both are instrumental for achieving energy efficiency improvements. They also point to the holistic nature of measures needed to accelerate desirable rates of industrial dematerialization and decarbonization.

\section{Impacts of Industrialization on Consumption and Leisure}

Industrialization had and continues to have far-reaching social impacts. Changes in 


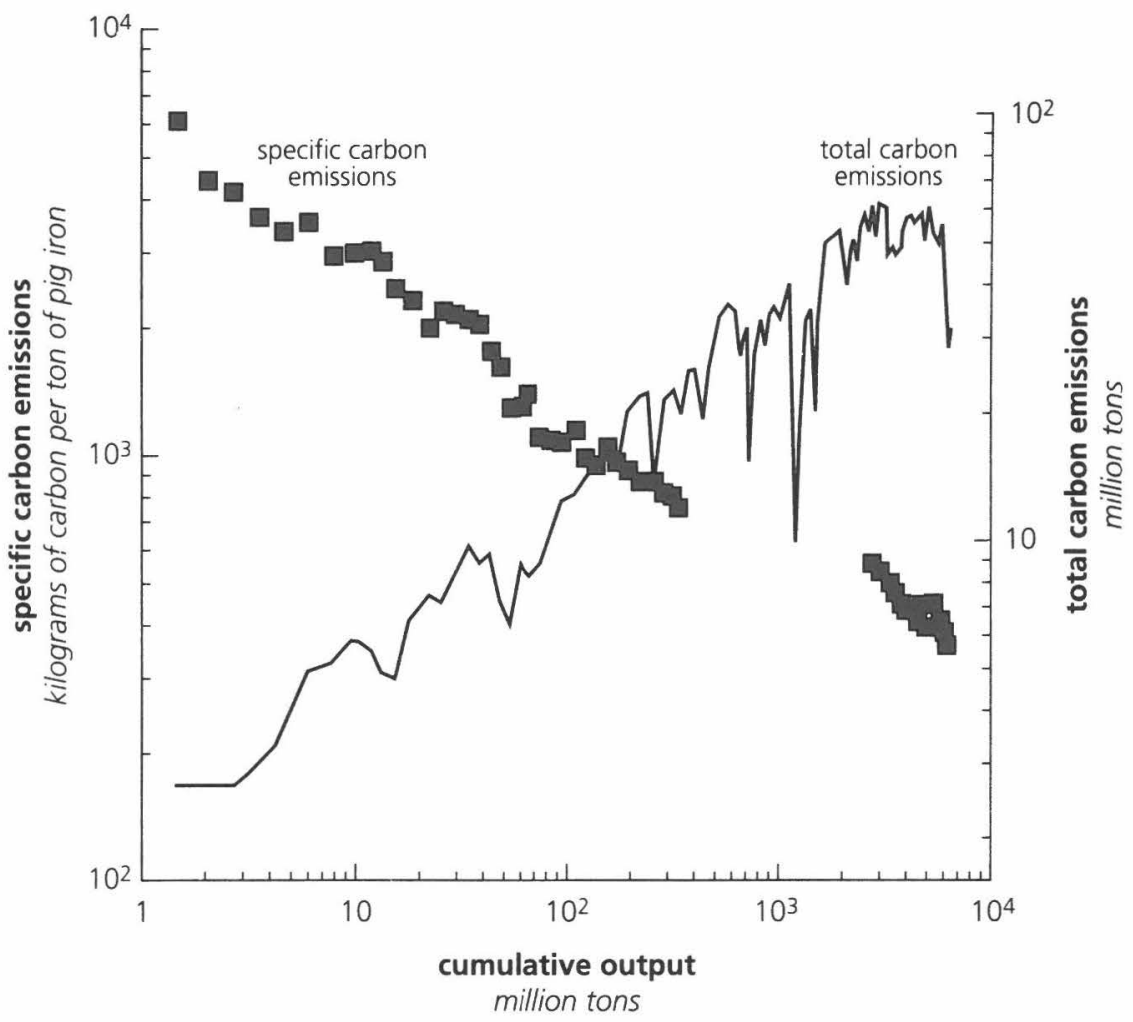

Figure 7. U.S. steel industry: specific and total sector carbon emissions vs. cumulative output. Carbon emissions from electricity production included in proportion of industrial to total final electricity consumption. Specific carbon emissions decrease by $17 \%$ for each doubling of cumulative output. Data source: Grübler, 1987; IEA, 1991.

employment structure, urbanization, increased life expectancy, rising incomes, and reductions in working time are examples of social changes directly and indirectly resulting from industrial output and productivity growth. Contingent on a social consensus, productivity gains have been distributed among rising wages and incomes (cf. Phelps Brown, 1973) and reductions of working time (Figure 10).

Perhaps the changes in time allocation patterns are among the least known of the social impacts of industrialization. Some 100 years ago, a U.K. laborer had an average life expectancy at the age of 10 of about 48 years and at age 20 of about 40 years, i.e., a total life span of less than 60 years. Before education became mandatory, labor began young, and essentially men who were healthy enough worked until they died (average length of a work career: about 47 years). Over his lifetime a male worker worked about 150,000 hours, or $60 \%$ of his available lifetime after subtracting necessary "physiological" time (i.e., the time required to eat and sleep). Today a typical male worker in the U.K. works some 88,000 hours during his lifetime. Due to reduced working time and increased life expectancy he spends 
Vulnerability and Adaptation

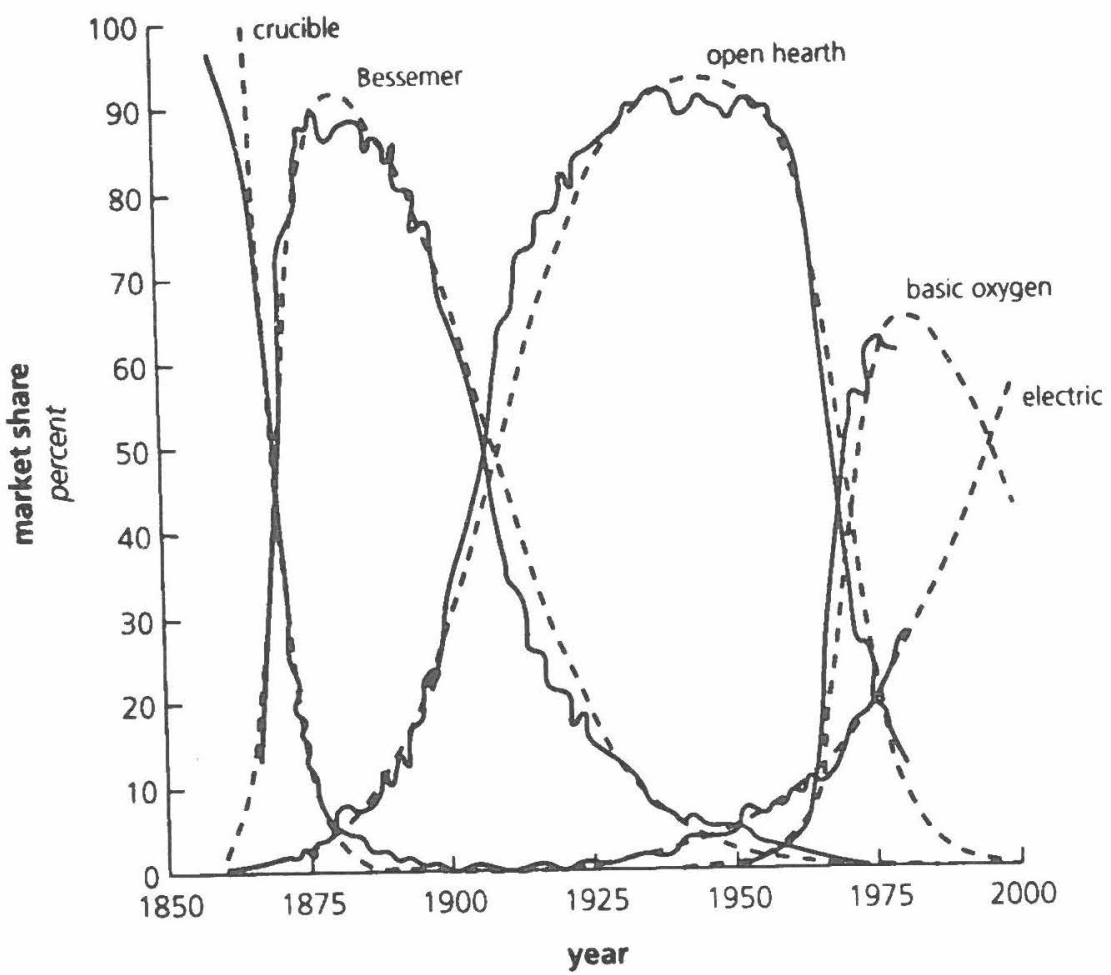

Figure 8. Relative market shares of different processes in raw steel production. Jagged lines are his. torical data and dashed lines model estimates by a set of coupled logistic equations. The dynamic pattern of technological change over time shown here is almost invariant across sectors and coun tries, but the timing and regularity of such technological substitution processes can vary considerably (Nakićenović, 1990).

only about $25 \%$ of his available lifetime at the work place. Trends in working time reductions (at paid work) for women have been less pronounced, but nevertheless noteworthy (cf. Ausubel and Grübler, 1990). International and intertemporal timebudget studies report on a broadly converging change in the structure of time allocation of the population (Figure 11).

More free time, coupled with higher incomes, has led to the development of lifestyles centered around private consumption and demand for services (cf. Gershuny, 1983). The structure of employment, industry, and production has followed suit. It is important to note to what extent resource consumption in postindustrial societies has become dominated by private consumption and leisure activities. Schipper et al. (1989) present data on final energy consumption for the FRG, indicating a dramatic shift in the relative share of energy consumption between productive (i.e., industrial) and consumptive (i.e., services and private households) uses of energy. Industry accounted in 1950 for two-thirds of final energy consumption, whereas today it accounts for only one-third. In future, it will become increasingly 


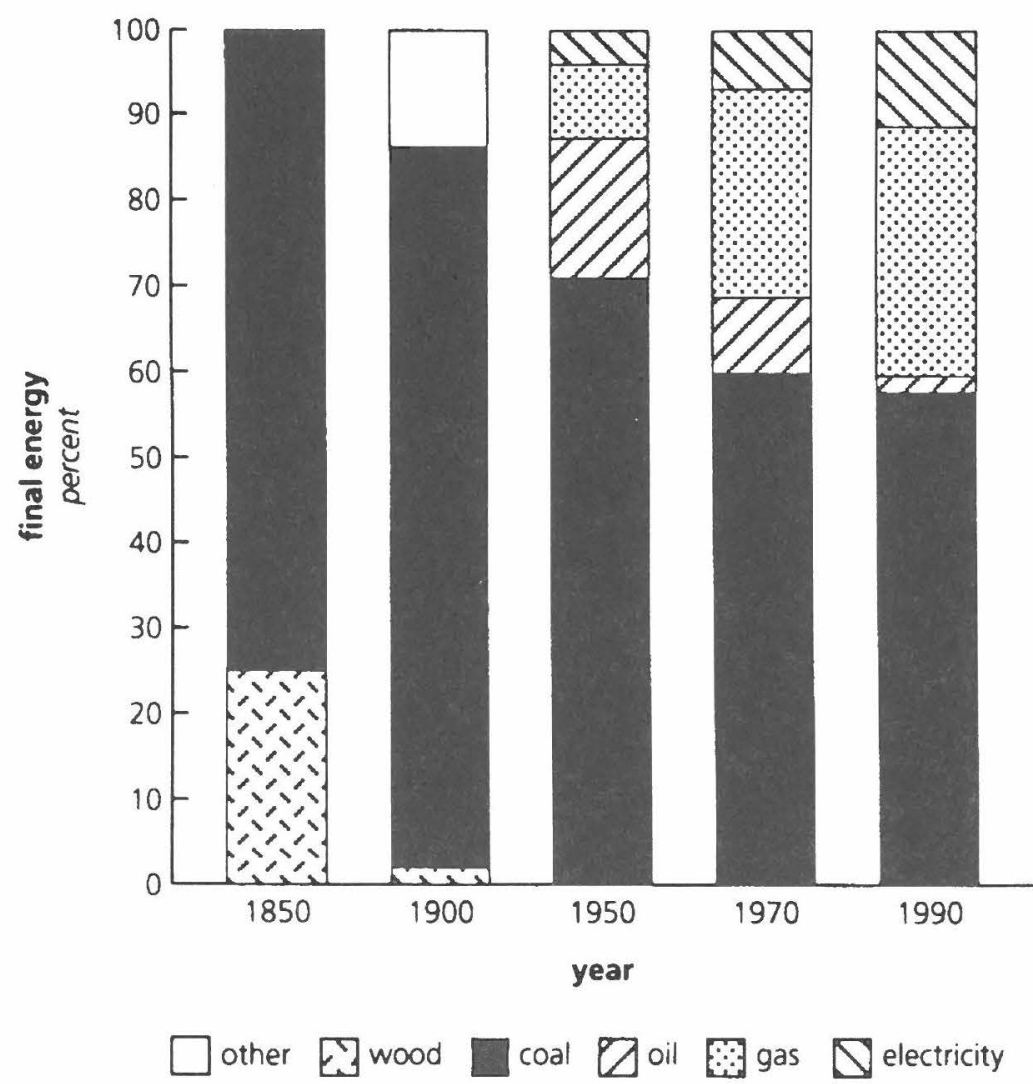

Figure 9. Structural changes in the U.S. steel industry fuel mix (percent of final energy). Changes in energy supply structures have accompanied changes in industrial process technologies (cf. Figure 8). Data source: 1850-1970: Grübler, 1987: 1990: IEA, 1991.

important for industry to take up the challenge to assist consumers in more environmentally compatible lifestyle choices - in providing not only new ("green") products, but also ways to ensure that environmentally friendly products are adopted, used and dispensed appropriately. All this implies redefining traditional markets for industrial products and services in the direction of integrated packages, focusing on the delivery of end-use services rather than on artifacts.

\section{Conclusion}

Industrialization as a historical phenomenon is conceptualized as a succession of phases, characterized by the pervasive adoption of "technology clusters." The introduction of a host of technological, institutional, and organizational innovations leads to productivity gains, impossible by a mere intensification of traditional solutions. From this perspective, industrialization is a time-specific phenomenon, 
Vulnerability and Adaptation

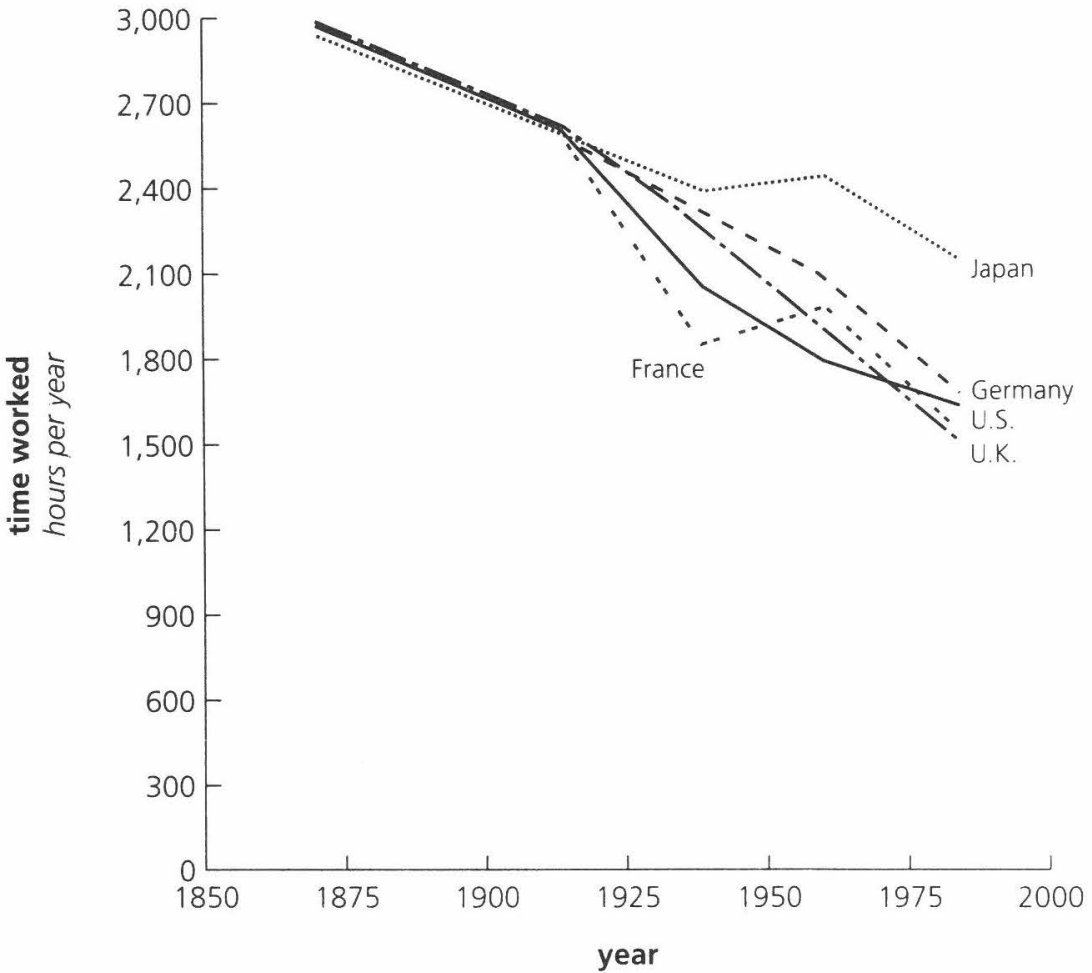

Figure 10. Hours worked per year in selected countries. Data source: Maddison, 1991.

characterized by (discontinuous) processes of change in the areas of economic structure, technological base, and social relations. History matters because of the cumulativeness of socio-institutional and technological change. This results in distinct development trajectories, spanning the extremes of high-intensity and highefficiency industrialization paths, clearly discernible from historical data.

With respect to environmental impacts, minimizing factor inputs is an inherent part of the incentive structure of industry. Improved factor productivity and lowered resource intensiveness of industrial production have historically accompanied structural changes in industry. In principle, industry is moving in the right direction, referred to here as dematerialization and decarbonization. This gives reasons to be cautiously optimistic, albeit historical trends will have to be accelerated significantly to reduce the absolute levels of emissions and environmental impacts. As in the past, changes in technology, energy, and transport infrastructures, and in social and institutional regulatory mechanisms, will be instrumental.

If environmental compatibility indeed could become a new dominant paradigm of industrial development, future sources of industrial growth will be primarily in this area. Such tendencies will be first discernible in the most advanced postindustrial economies (i.e., in the industrial core). It is our contention that (as in the past) 


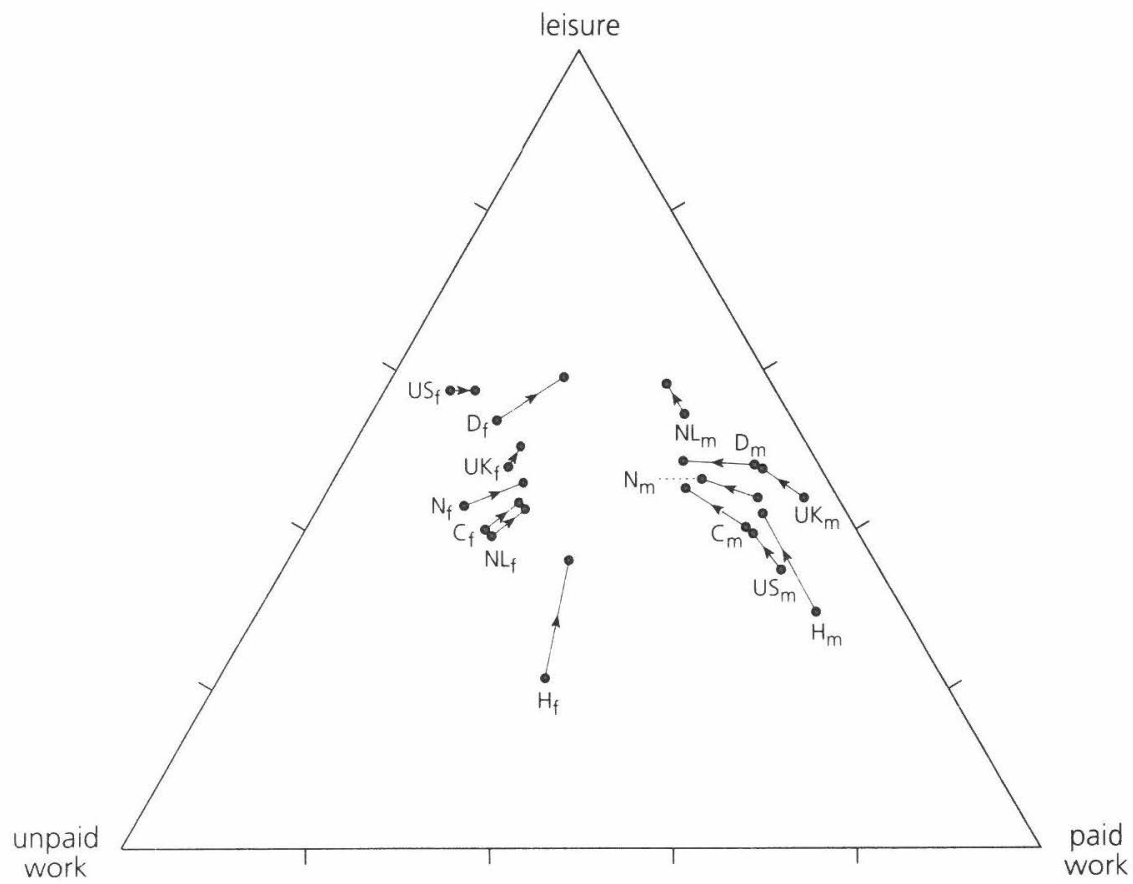

Figure 11. Relative allocation of time budgets to different activities, male and female population of seven countries, 1960s to 1980s. The figure illustrates an international and gender convergence away from formal, contracted work to unpaid work (e.g., family care) and leisure activities. This transition in activity patterns can also be clearly discerned in energy demand statistics. In industrialized countries today about two-thirds of final energy is consumed outside the productive sphere (i.e., industry) for services and leisure uses of energy (source: Gershuny, 1992).

successful catching up will only be possible if based on technological and institutional solutions not in conflict with the dominant industrial paradigm of the core.

Industrialization has brought tremendous productivity gains and resulting rising incomes and reduced working time-in short, affluence and leisure. From an environmental perspective activities outside the productive sphere are increasingly the determinants of resource consumption and environmental impacts. Furthermore, private and leisure activities are more difficult to steer with traditional policy instruments, such as price signals to which industry adheres. The decision-making criteria of consumers are complex and far from the rationality concepts underlying most economic models. Perhaps this will provide the largest future challenge to industry: providing consumers not with products, but with environmentally friendly integrated solutions to satisfy a particular service demand.

\section{Acknowledgments}

Comments by Bob Chen and Jerry Schnoor, and assistance of Andreas Schäfer in the preparation of the tables and figures, are gratefully acknowledged. 


\section{Vulnerability and Adaptation}

\section{References}

Ausubel, J. H., and A. Grübler. 1990. Working Less and Living Longer. Part I: Long-term Trends in Working Time and Time Budgets. International Institute for Applied Systems Analysis, Laxenburg, Austria.

Ausubel, J. H., A. Grübler, and N. Nakicenovic. 1988. Carbon Dioxide Emissions in a Methane Economy. Report No. RR-88-7, International Institute for Applied Systems Analysis, Laxenburg, Austria.

Bairoch, P. 1982. International industrialization levels from 1750 to 1980. Journal of European Economic History 11, 269-333.

Brooks, H. 1988. Some Propositions About Sustainability. Harvard University, Cambridge (draft).

Chenery, H., S. Robinson, and M. Syrquin (eds.). 1986. Industrialization and Growth: A Comparative Study. Oxford University Press, Oxford, U.K., 387 pp.

Clark, C. 1940. The Conditions of Economic Progress. Macmillan Press, London, U.K., 589 pp.

de Solla-Price, D. J. 1963. Little Science, Big Science. Columbia University Press, New York, 118 pp.

Economist. 1990. Vital World Statistics: A Complete Guide to the World in Figures. The Economist Books Limited, London, U.K.

Fishlow, A. 1965. American Railroads and the Transformation of the Antebellum Economy. Harvard University Press, Cambridge, Massachusetts.

Freeman, C. 1989. The Third Kondratieff Wave: Age of Steel, Electrification and Imperialism. Research Memorandum 89-032, MERIT, Maastricht, Netherlands.

Gershuny, J. I. 1983. Social Innovation and the Division of Labour. Oxford University Press, Oxford, U.K.

Gershuny, J. I. 1992. La répartition du temps dans les societés post-industrielles. Futuribles $165-166,215-226$.

Glaziev, S. 1991. Economic Theory and Technological Change. Nauka, Moscow, Russia, 232 pp. (In Russian)

Gray, P. E. 1989. The paradox of technological development. In Technology and Environment (J.H. Ausubel et al., eds.), National Academy Press, Washington, D.C., 192-204.

Grigg, D. B. 1987. The industrial revolution and land transformation. In Land Transformation in Agriculture (M.G. Wolman and F.G.A. Fournier, eds.), John Wiley and Sons, Chichester, U.K., 79-109.

Grübler, A. 1987. Technology diffusion in a long wave context: The case of the steel and coal industries. In Proceedings of the International Workshop on Life Cycles and Long Waves, Montpellier, France, July 8-10, 1987. International Institute for Applied Systems Analysis, Laxenburg, Austria.

Grübler, A. 1990. The Rise and Fall of Infrastructures, Dynamics of Evolution and Technological Change in Transport. Physica Verlag, Heidelberg, Germany, 305 pp.

Grübler, A. 1992. Technology and Global Change: Land-use, Past and Present. Report No. WP-922, International Institute for Applied Systems Analysis, Laxenburg, Austria.

Haustein, H.-D., and E. Neuwirth. 1982. Long Waves in World Industrial Production, Energy Consumption, Innovations, Inventions, and Patents and Their Identification by Spectral Analysis. Report No. WP-82-9, International Institute for Applied Systems Analysis, Laxenburg, Austria.

Hobsbawn, E. J., and G. Rudé. 1968. Captain Swing. Pantheon Books, New York. 


\section{A. Grübler: Industrialization as a Historical Phenomenon}

Hoffmann, W. G. 1931. Studien und Typen der Industrialisierung. Ein Beitrag zur quantitativen Analyse historischer Wirtschaftsprozesse. Revised English translation: Hoffmann, W.G. 1958. The Growth of Industrial Economies. Manchester University Press, Manchester, U.K.

IEA (International Energy Agency). 1991. Energy Statistics of OECD Countries 1960-1989. Vols. I and II, IEA, Paris, France.

ILO (International Labor Office). 1991. Yearbook of Labour Statistics. ILO, Geneva, Switzerland.

IRF (International Road Federation). 1991. World Road Statistics. IRF, Washington, D.C.

Kuznets, S. S. 1958. Six Lectures on Economic Growth. Free Press, New York.

Landes, D. S. 1969. The Unbound Prometheus: Technological Change and Industrial Development in Western Europe From 1750 to the Present. Cambridge University Press, Cambridge, U.K.

Liesner, T. (ed.). 1985. Economic Statistics 1900-1983. The Economist Publications Limited, London, U.K.

Maddison, A. 1991. Dinamic Forces in Capitalist Development, a Long-run Comparative View. Oxford University Press, Oxford, U.K., 333 pp.

Marland, G., and A. Pippin. 1990. United States emissions of carbon dioxide to the earth's atmosphere by economic activity. Energy Systems and Policy 14, 319-336.

Mitchell, B. R. 1980. European Historical Statistics: 1750-1975. Macmillan Press, London, U.K.

Mitchell. B. R. 1982. International Historical Statistics: Africa and Asia. MacMillan Press, London, U.K.

Mitchell, B. R. 1983. International Historical Statistics: The Americas and Australia. Macmillan Press, London, U.K.

Mokyr, J. 1990. The Lever of Riches, Technological Creativity and Economic Progress. Oxford University Press, Oxford, U.K.

MVMA (Motor Vehicle Manufacturers Association of the United States, Inc.). 1991. World Motor Vehicle Data. MVMA, Detroit, Michigan.

Nakićenović, N. 1990. Dynamics of change and long waves. In Life Cycles and Long Waves (T. Vasko, R. Ayres and L. Fontvielle, eds.), Lecture Notes in Economics and Mathematical Systems, Springer Verlag, Berlin, Germany, 147-192.

Nakićenović, N., A. Grübler, L. Bodda, and P.-V. Gilli. 1990. Technological Progress, Structural Change and Efficient Energy Use: Trends Worldwide and in Austria. International part of a study supported by the Österreichische Elektrizitätswirtschaft AG, International Institute for Applied Systems Analysis, Laxenburg, Austria.

O'Brien, P. (ed.) 1983. Railways and the Economic Development of Western Europe 1830-1914. Macmillan Press, London, U.K.

Perez, C. 1983. Structural change and the assimilation of new technologies in the economic and social system. Futures 15(4), 357-375.

Phelps Brown, E. H. 1973. Levels and movements of industrial productivity and real wages internationally compared, 1860-1970. The Economic Journal 83(329), 58-71.

Rosenberg, N., and L. E. Birdzell. 1986. How the West Grew Rich: The Economic Transformation of the Industrial World. I.B. Tauris and Co., London, U.K.

Rostow, W. W. 1978. The World Economy: History and Prospect. University of Texas Press, Austin, Texas, $833 \mathrm{pp}$.

Schipper, L., S. Bartlett, D. Hawk, E. Vine. 1989. Linking life-styles and energy: A matter of time? Annual Review of Energy 14, 273-320. 


\section{Vulnerability and Adaptation}

Schumpeter, J. 1939. Business Cycles: A Theoretical, Historical and Statistical Analysis of the Capitalist Process. Vols. I and II, Mc-Graw Hill, New York.

Tunzelmann, G. N. 1982. Structural change and leading sectors in British manufacturing 1907-1968. In Economics in the Long View, Vol. 3 Part 2: Applications and Cases (C.P. Kindleberger and G. di Tella, eds.), New York University Press, New York, 1-49.

U.N. (United Nations). 1990. 1987 Statistical Yearbook. U.N., New York.

Williams, R. H., E. D. Larson, and M. H. Ross. 1987. Materials, affluence. and industrial energy use. Annual Review of Energy 12, 99-144.

World Bank. 1992. World Development Report 1992: Development and the Enviromment. Oxford University Press, Oxford, U.K.

Woytinsky, W. L., and E. S. Woytinsky. 1953. World Population and Production. Trends and Outlook. The Twentieth Century Fund, New York, 1268 pp. 
